\title{
Taxonomic notes on Vestistilus affinis (Fairmaire) (Hemiptera, Membracidae)
}

\author{
Gabriel S. de Andrade \\ Centro de Ciências Biológicas e da Saúde, Universidade Estadual do Oeste do Paraná. Rua Universitária 2069, Caixa Postal \\ 711, 85819-110 Cascavel, Paraná, Brasil. E-mail: gsa@certto.com.br
}

\begin{abstract}
This paper deals with Vestistilus affinis (Fairmaire, 1846) = Ceresa testacea Fairmaire, 1846 syn. nov. = Ceresa stalii Butler, 1877 syn. nov. Lectotypes are designated for Ceresa affinis Fairmaire and Ceresa testacea Fairmaire. Both species are illustrated; a figure of the male genitalia of $C$. testacea is also given.

KEY WORDS. Ceresini, Membracoidea, Smiliinae, systematics, taxonomy.
\end{abstract}

\begin{abstract}
RESUMO. Notas taxonômicas sobre Vestistilus affinis (Fairmaire) (Hemiptera, Membracidae). São tratados Vestistilus affinis (Fairmaire, 1846) = Ceresa testacea Fairmaire, 1846 syn. nov. = Ceresa stalii Butler, 1877 syn. nov. Lectótipos são designados para Ceresa affinis Fairmaire e Ceresa testacea Fairmaire. Ambas espécies são ilustradas; é apresentada também figura da genitália masculina de $C$. testacea.
\end{abstract}

PALAVRAS CHAVE. Ceresini, Membracoidea, sistemática, Smiliinae, taxonomia.

The genus Vestistilus was described by CaLDwell (1949) to accomodate some species formerly described in Ceresa Amyot \& Serville, 1843. A reappraisal of the taxon was made by Kopp \& YoNKE (1979). ANDRADE (1989) added one more species to the genus. In the updated catalogue of McKamEY (1998) there were listed seven species. More recently, ANDRADE (2003) transferred species for the new described genus Vestistiloides, and ANDRADE (2004b) also proposed a new combination for C. affinis Fairmaire, 1846 in the genus, thus currently remain in Vestistilus, only V. affinis (Fairmaire, 1846), V. ancora (Ball, 1937), V. patruclis (Stål, 1864), V. testaceus (Fairmaire, 1846) and V. vacca (Fowler, 1895). During the revisionary study of the genus Ceresa Amyot \& Serville and the cladistic analysis of Ceresini, the type-series of some species described by FaIrmaire (1846) have been located and studied, and together with material described by ButLer (1877) and Fowler (1895) made possible the present notes to contribute for the understanding of the genus Vestistilus Caldwell, 1949. The geographical distribution of the genus is recorded mostly from Central America, with records also from Arizona and South America.

\section{Vestistilus affinis (Fairmaire, 1846)}

Figs $1-5$

Ceresa affinis Fairmaire, 1846: 284; McKamey, 1998: 244 (cat.). Vestistilus affinis; Andrade, 2004b: 735.

Ceresa testacea Fairmaire, 1846: 284. Syn. nov.

Vestistilus testaceus; McKamey, 1998: 262 (cat.).

Ceresa stalii Butler, 1877: 217. Syn. nov.

Ceresa stalii; McKamey, 1998: 246 (cat., = C. cavicornis Stål, 1859). Error.

Fairmaire (1846), when described the species, did not state the number of examined specimens, just indicating "Coll. Spinola" as being the repository of the material.
We examined one of the three syntypes, a female, existing in the collection M. Spinola, deposited at the "Museo Regionale di Scienze Naturali", Torino, Italy. It is here designated as the lectotype of C. affinis Fairmaire, 1846. This designation is important since the Ceresini includes several criptical species. According to Casale (1981), the constant data in the pertinent box's label of the specimen are "Ceresa affinis Spinola, Brésil and Dupont". The information on the type-locality and the characters presented by the specimen are compatible with the original description and illustrations.

Notes on the lectotype of C. affinis. The specimen is in a reasonable state of conservation, pinned, with the abdomen not dissected, and superficially covered with mould and dust. The pronotum is slightly free, lack the right antenal flagellum, lack also the thigh, trochanter, femur, tibia and tarsus left II, and the right posterior tibia is slightly loose.

Measurements (in millimeter) of the lectotype of $C$. affinis. Width of head: 3.60; length of head: 1.80; distance between humeral angles: 4.20; distance between apex of suprahumeral horns: 7.00; length of pronotum: 10.00; total length: 11.16 .

Fairmaire (1846), when described C. testacea, did not state the number of examined specimens, just indicating "Coll. Signoret" as being the repository of the studied material.

We examined one of the several syntypes, a male, existing in the collection Signoret, deposited in the "Naturhistorisches Museum Wien", Wien, Austria. It is here designated as the lectotype of C. testacea Fairmaire, 1846. The designation is important since the Ceresini includes several criptical species. The labels appended to the specimen are "Coll. Nat. Mus. Wien.", "Mexico / Coll. Signoret.", "testacea / det. Signoret." and "testacea / det. Fowler.". These labels are of the same style 

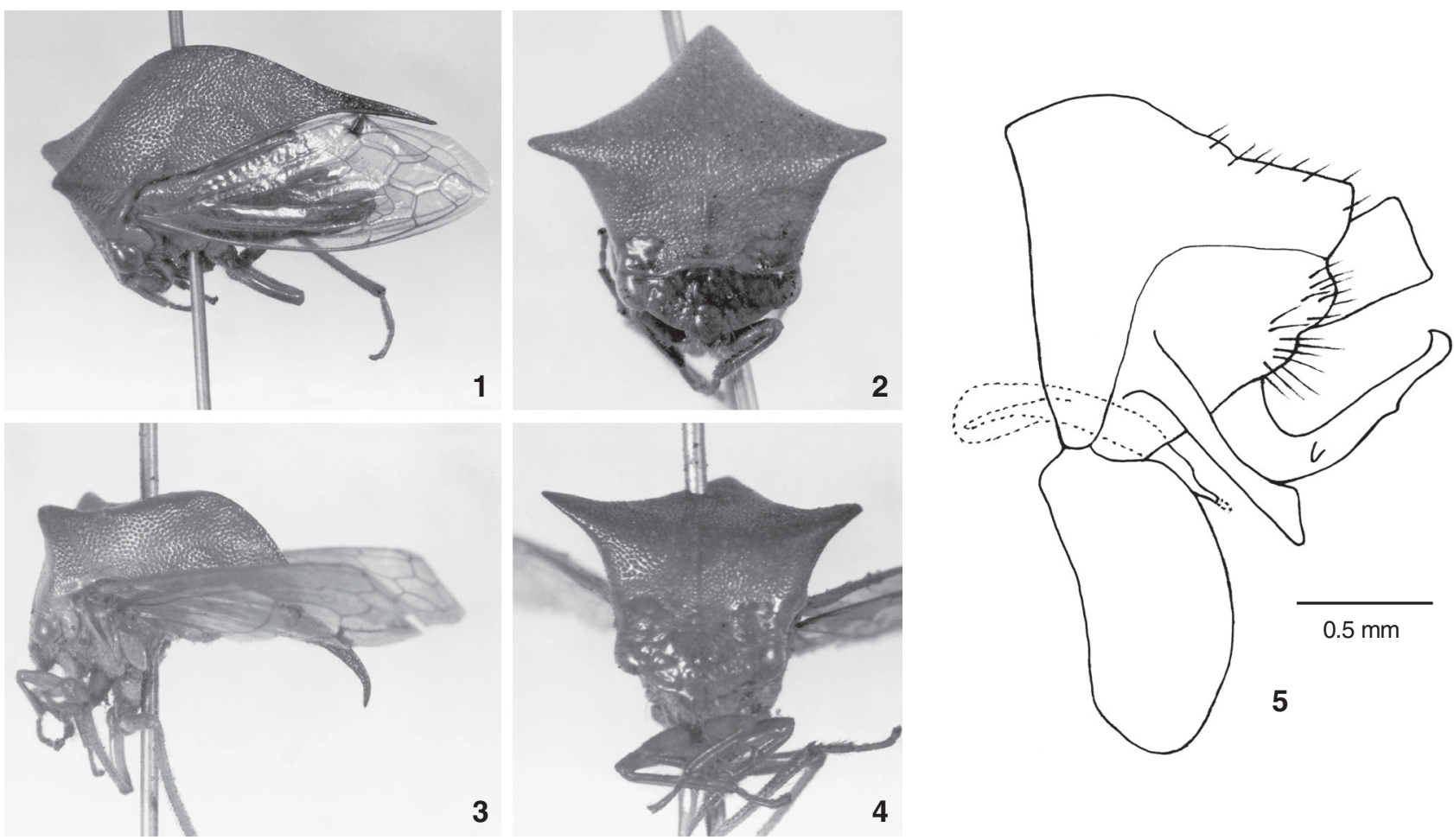

Figures 1-5. (1-2) Ceresa affinis, female lectotype: (1) lateral view; (2) frontal view; (3-5) Ceresa testacea, male lectotype: (3) lateral view; (4) frontal view; (5) genitalia of the male lectotype, lateral view.

of those found by ANDRADE (2004a) for Spissistilus puncticeps (Stål, 1864), indicating that they are not original. The information on the type-locality and the characters presented by the specimen are compatible with the original description.

Notes on the lectotype of $C$. testacea. The specimen is in a reasonable state of conservation, pinned, with the abdomen dissected, a little free from the pin, and covered superficially with mould and dust. The apex of the left suprahumeral horn is broken; the tegmina and wings are extended, the apex of the left tegmem is torn; lacks left tarsus III. The specimen also presents a disformity at the posterior pronotal process, being curved down.

Measurements (in millimeter) of the lectotype of $C$. testacea. Width of head: 3.20; length of head: 1.60; distance between humeral angles: 3.70 ; distance between apex of the suprahumeral horns: 6.10 ; length of pronotum: 8.17 ; total length: 10.17 .

The comparative studies of the lectotype of C. affinis, lectotype of C. testacea, and of the holotype of C. stalii Butler, 1877 (deposited at "The Natural History Museum", London), show that they belong to the same species, despite of the different type-localities originally referred, especially between $C$. affinis and C. testacea.

The specimens interpreted as C. affinis by Remes-Lenicov
(1973) show that they are actually C. denticulata Andrade, 2002. In same way, the material interpreted also as $C$. affinis by Kopp \& Yonke (1979) is C. amazonica Andrade, 2002. On the other hand, the synonymy of $C$. stalii with C. cavicornis, proposed by Goding (1929), is inconsistent according to the data of ANDRADE (2004b) for this species. All decisions were taken after examining the types.

\section{ACKNOWLEDGEMENTS}

Thanks are due to Drs A. Casale (Museo Regionale di Scienze Naturali, Torino, Italia) and U. Aspöck (Naturhistorisches Museum Wien, Wien, Austria), for loan of type material; to M.D. Webb (The Natural History Museum, London, UK), for his courtesy during my visit to the Institution and opportunities for the studies in the Membracidae collections, and to Prof. Dr Albino Morimasa Sakakibara (Universidade Federal do Paraná, Curitiba, Brasil), for some helps during the initial studies and kindness for photograph procedures.

\section{REFERENCES}

Andrade, G.S. 1989. Uma nova espécie do gênero Vestistilus Caldwell, 1949 (Homoptera: Membracidae). Revista Brasi- 
leira de Zoologia, Curitiba, 6 (2): 263-266.

ANDRADE, G.S. 2002. Sobre quatro novas espécies de Ceresa Amyot \& Serville (Hemiptera, Auchenorrhyncha, Membracidae). Revista Brasileira de Zoologia, Curitiba, 19 (Supl. 2): 39-51. Andrade, G.S. 2003. Vestistiloides, um novo gênero de Ceresini (Hemiptera, Auchenorrhyncha, Membracidae). Revista Brasileira de Zoologia, Curitiba, 20 (1): 1-2.

Andrade, G.S. 2004a. Novas combinações e sinonímia em Spissistilus Caldwell (Hemiptera, Auchenorrhyncha, Membracidae). Revista Brasileira de Zoologia, Curitiba, 21 (1): 43-44.

Andrade, G.S. 2004b. As espécies do gênero Ceresa Amyot \& Serville (Hemiptera, Auchenorrhyncha, Membracidae). Revista Brasileira de Zoologia, Curitiba, 21 (4): 671-738.

ButLer, A.G. 1877. On various genera of the homopterous family Membracidae with descriptions of new species. Cistula Entomologica, London, 2: 205-222.

Caldwell, J.S. 1949. A generic revision of the treehoppers of the tribe Ceresini in America north of Mexico, based on a study of the male genitalia. Proceedings of the United States National Museum, Washington, 98: 491-521.

Casale, A. 1981. Cataloghi II. Collezione Emitterologica di Massimiliano Spinola. Torino, Museo Regionale di Scienze Naturali, 120p.
Fairmaire, L.H.M. 1846. Revue de la tribu des Membracides. Annales de la Société Entomologique de France, Paris, 4: 235-320.

Fowler, W.W. 1895. Order Rhynchota. Suborder Hemiptera-Homoptera, p. 89-112. In: F.D. Godman \& O. SALvin. Biologia Centrali-Americana.

Goding, F.W. 1929. The Membracidae of South America and the Antilles. IV. Subfamilies Hoplophorioninae, Darninae, Smiliinae, Tragopinae (Homoptera). Transactions of the American Entomological Society, Philadelphia, 55: 197330.

Kopp, D.D. \& T.R. YonKe. 1979. A taxonomic review of the tribe Ceresini (Homoptera: Membracidae). Miscellaneous Publications of the Entomological Society of America, College Park, 11 (2): 1-97.

McKamey, S.H. 1998. Taxonomic catalogue of the Membracoidea (Exclusive of Leafhoppers). Second supplement to Fascicle 1 - Membracidae of the General Catalogue of the Hemiptera. Memoirs of the American Entomological Institute, Gainesville, 60: 1-377.

Remes-Lenicov, A.M.M. 1973. Contribución al estudio de los Membrácidos neotropicales I. Revisión del género "Ceresa" (sic) Amyot et Serville. Acta Zoologica Lilloana, Tucuman, 30: 53-134.

Received in 12.VII.2005; accepted in 28.VIII.2005. 